\title{
Immune System Finding
}

National Cancer Institute

\section{Source}

National Cancer Institute. Immune System Finding. NCI Thesaurus. Code C39723.

Symptoms, physical examination results, and/or laboratory test results related to the immune system. 